\title{
Pendampingan Pembuatan Konten Virtual Tourism sebagai Inisiasi Living Lab Cagar Budaya Kampoeng Heritage Kayoetangan
}

\author{
Aniesa Samira Bafadhal \\ Program Studi S1 Pariwisata, Universitas Brawijaya, Malang, Indonesia, \\ email:aniesa.bafadhal@ub.ac.id
}

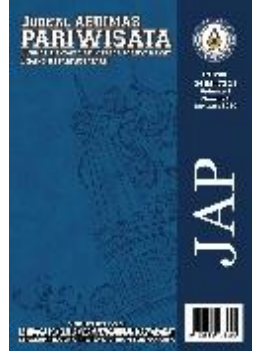

\begin{tabular}{|c|c|}
\hline Informasi artik & \\
\hline $\begin{array}{l}\text { Sejarah } \\
\text { artikel }\end{array}$ & \\
\hline Diterima & : 20 Mei 2020 \\
\hline Revisi & : 20 Juni 2020 \\
\hline Dipublikasikan & : 1 Juli 2020 \\
\hline
\end{tabular}

Kata kunci:

Pariwisata Virtual

Realitas Virtual

Lab Hidup

Pendampingan Masyarakat

\begin{abstract}
ABSTRAK
Pengelolaan destinasi wisata yang merangkap sebagai situs cagar budaya dan rumah tinggal warga seperti Kampoeng Wisata Heritage Kojoetangan, Kota Malang bertendensi mengandung beberapa permasalahan yang harus segera ditangani bersama karena dikhawatirkan jika tidak segera dibenahi hanya akan menjadi euforia budaya yang berumur singkat. Salah satu solusi yang bisa digunakan adalah melalui inisiasi kerjasama berbasis lab hidup (living lab) dalam bentuk co-creation pembuatan konten pariwisata virtual (virtual tourism) berbasis teknologi realitas virtual (virtual reality) dengan mempertimbangkan informasi dan kebutuhan para pemangku kepentingan yaitu, pemerintah setempat, pengelola destinasi, wisatawan, warga di Kampoeng Wisata Heritage Kojoetangan. Pengabdian kepada Masyarakat ini merupakan implementasi dari action reseach dalam bentuk pendampingan kepada pengelola destinasi yaitu Kelompok Sadar Wisata (Pokdarwis). Kolaborasi antar Public. Private, People Partnership dalam bentuk pengelolaan bersama virtual tourism Kampoeng Heritage Kayoetangan sebagai living lab dapat meningkatkan nilai pengalaman wisata secara konkret dengan mendorong interaksi, co-creation, dan peningkatan personalisasi produk wisata virtual yang dinilai mampu menjawab permasalahan destinasi tersebut
\end{abstract}

\begin{abstract}
The management of tourist destinations that not only have a function as a cultural heritage site but also residents' homes such as Kampoeng Wisata Heritage Kojoetangan, Malang City has a tendency to contain several problems that must be face together because it is feared that if it is not immediately fixed it will only be a short-lived cultural euphoria. One solution that can be used is through the initiation of a living labbased collaboration in the form of co-creation of virtual tourism content creation based on virtual reality websites by considering the information and needs of stakeholders, namely, local government, destination managers, tourists, residents in Kampoeng Wisata Heritage Kojoetangan. . This community service is an implementation of action reseach in the form of assistance to destination managers, namely the Tourism Awareness Group (Pokdarwis). Collaboration between Public. Private, People Partnership in the form of joint management of the Kampoeng Heritage Kayoetangan virtual tourism as a living lab can increase the value of the tourism experience in a concrete manner by encouraging interaction, co-creation, and increasing personalization of virtual tourism products that are considered capable of answering the destination's problems.
\end{abstract}




\section{Pendahuluan}

Kota Malang pada era kolonial dikenal dengan sebutan "de bloemenstad" dan disebut sebagai "kota pensiun" bagi orang-orang Belanda yang tidak kembali ke Negara Belanda dan juga "Paris van oost Java" karena digadang sebagai hasil perencanaan kota kolonial yang terbaik di Hindia Belanda pada awal abad ke-20. Sebuah langkah konkrit telah diambil untuk memunculkan kembali identitas ruang kota melalui penobatan secara resmi Kota Malang sebagai Kota Heritage. Kampung Heritage Kajoetangan yang terletak di Jalan Jendral Basuki Rachmat Gang VI, Kauman, Klojen, Kota Malang, Jawa Timur telah ditetapkan sebagai Kawasan cagar budaya dan secara resmi dibuka sejak 22 April 2018 oleh pemerintah Kota Malang (Radar Malang, 2018). Masa Kolonial Belanda selama ratusan tahun telah menyebabkan akulturasi kebudayaan Barat kedalam berbagai aspek kebudayaan bangsa Indonesia tidak terkecuali dalam hal arsitektur dan interior bangunan.

Dari segi fisik, gaya arsitektur Kolonial milik warga Belanda mempengaruhi gaya arsitektur rumah orang pribumi. Pada saat itu muncul anggapan bahwa rumah orang yang berstatus sosial tinggi dan ideal adalah rumah bergaya Kolonial, untuk rumah pemukiman kolonial yang berkembang di Kampoeng Heritage Kayoetangan banyak mendapat pengaruh budaya Jawa dan Kolonial dalam hal wujud fisik rumah. Umumnya bergaya "Voor 1900" menggambarkan detail rumah yang bercirikan kolom besi cor berukuran ramping, plafon, atap bentuk perisai, denah yang simetris, teras yang terbuka, pagar besi, teralis jendela, yang dipadu dengan gaya Jawa berupa ornamen lisplank/ teritisan dan gaya joglo (Cahyani, dkk 2015).

Bangunan rumah peninggalan kolonial pada Kampoeng Wisata Heritage Kojoetangan yang menjadi situs cagar budaya sekaligus objek wisata mengandung permasalahan kompleks terutama jika rumah tersebut masih digunakan warga setempat untuk aktivitas sehari-hari. Beberapa permasalahan yang dapat diidentifikasi dari pengelolaan destinasi wisata sekaligus situs cagar budaya di Kampoeng Heritage Kajoetangan yaitu pertama, masalah masalah privasi dan dualisme fungsi ruang pada rumah penduduk sekitar. Kehadiran wisatawan dapat saja menggangu kehidupan sehari-hari warga terlebih lagi peneliti menemukan bahwa belum semua warga memahami dan menyepakati konsep wisata kampung tematik tersebut sehingga bisa berpotensi miskomunikasi.

Kedua, terkait dengan daya tampung dan daya dukung destinasi wisata cagar budaya yang memprihatinkan. Rendahnya daya tampung dan daya dukung destinasi wisata untuk penduduk lokal dan wisatawan juga dapat merusak situs cagar budaya (Cimnaghi and Mussi, 2015), terlebih secara kasat mata terlihat bahwa Kampoeng Heritage Kayoetangan tidak memiliki anemitas yang memadai seperti akses jalanan berupa gang sempit dan sulitnya lahan parkir sehingga popularitas, komersialisasi, pariwisata massal dan ekses negative pariwisata dapat mengganggu preservasi situs sekaligus menurunkan kepuasan wisatawan.

Ketiga, meningkatnya ekses negatif pariwisata terhadap preservasi situs cagar budaya disebabkan oleh popularitas wisata cagar budaya tersebut di kalangan wisatawan. Berbagai aktivitas dan perilaku wisatawan juga dapat membahayakan (detrimental tourist behavior) situs budaya seperti pencurian data vital dan properti kebudayaan (Kaboteet al, 2016), vandalism (Gaigher, 2011), pengrusakan (Ruoss and Alfare, 2013), perubahan bentang alam karena kelalaian manusia (Pwiti, 2011), pembuangan sampah sembarangan (Uchiyama, 2012) dan polusi (Furuuchi et al, 2007),

Keempat, ketidakpedulian masyarakat yang meningkat juga dapat menyebabkan kerusakan pada situs (Nyaupane and Timothy, 2016). Sebagai contoh, pada saat memasuki gang yang terdapat di Jalan Kawi terdapat gambar peta dari Kampoeng Wisata Heritage Kojoetangan. Semua informasi fasilitas sudah ada denahnya pada peta. Informasi ini cukup menarik untuk dibaca oleh wisatawan karena jika sejarah tidak menarik untuk dibaca, maka tidak akan ada minat untuk mempelajari sejarah (Khakim, 2016). Sayangnya, Famukhit et al (2013) menyatakan kepentingan publik dalam pelestarian budaya Indonesia telah menurun, terutama generasi muda, hal ini berdasarkan data dari Departemen Kebudayaan dan Pariwisata pada tahun 2005-2009. Penurunan minat masyarakat terhadap budaya, karena kurangnya media komunikasi yang digunakan menarik. Saat ini masyarakat milenial lebih menyukai informasi dalam bentuk visual interaktif dibandingkan dengan teks monoton. 
Kelima, perencanaan dan tata kelola yang kurang terorganisasi oleh pihak terkait dan cenderung bersifat seremonial dan episodikal dapat mengurangi citra, identitas ruang dan keberlanjutan Kampoeng Wisata Heritage Kojoetangan. Dapat dipahami hal tersebut disebabkan masih baru diresmikannya kawasan wisata ini sehingga pengelolaan belum berjalan baik dimana banyak warga sekitar yang belum memahami konsep wisata tersebut dan wisatawan juga tidak mengetahui bagaimana seharusnya kampung wisata ini berjalan karena minimnya informasi. Selain itu, kegiatan tanpa perencanaan yang matang seperti pembangunan baik perubahan fungsi bangunan, penambahan bentuk asli ataupun pembongkaran (Barrera-Fernandez et al, 2016), dampak kepadatan penduduk (García-Hernández et al, 2017), atau justru perencanaan dan komersialisasi pariwisata yang ambisius (Nasser, 2003) juga dapat mengancam keberlangsungan bangunan peninggalan kolonial sebagai situs cagar budaya, destinasi dan sekaligus rumah tinggal penduduk Kampoeng Wisata Heritage Kojoetangan.

Berangkat dari berbagai permasalahan tersebut, salah satu solusi yang bisa digunakan adalah melalui inisiasi kerjasama berbasis living lab dalam bentuk pembuatan konten virtual tourism oleh pengelola destnasi dengan mempertimbangkan informasi dan kebutuhan para pemangku kepentingan yaitu, pemerintah setempat, pengelola destinasi, wisatawan, warga di Kampoeng Wisata Heritage Kojoetangan.

Pallot (2006) berpendapat bahwa laboratorium hidup (living lab) bukanlah laboratorium penelitian tradisional atau "testbed", melainkan "platform inovasi" yang menyatukan dan melibatkan semua pemangku kepentingan seperti pengguna, peneliti, industrialis, pembuat kebijakan, dan sebagainya pada tahap awal proses inovasi untuk menguji konsep terobosan dan nilai potensial bagi masyarakat (citizen) dan pengguna yang akan mengarah pada terobosan inovasi. Secara bentuk wilayah, living lab dapat berbentuk wilayah fisik ataupun virtual reality di mana para pemangku kepentingan membentuk Public-Private-People Partnership (PPPP) dari perusahaan, lembaga publik, universitas, lembaga, dan pengguna semua berkolaborasi untuk perencanaan, pembuatan prototipe, validasi, dan pengujian teknologi baru, layanan, produk, dan sistem dalam konteks kehidupan nyata "(Westerlund and Leminen, 2011).

Dalam pengembangan living lab virtual tourism Kampoeng Heritage Kayoetangan, pemerintah daerah dapat menyediakan kebijakan dan memiliki kewenangan untuk membantu pendanaan, menetapkan situs cagar budaya dan mendorong secara legal formal kepada masyarakat untuk kooperatif memberikan informasi dan kesediaan akses rumah peninggalan kolonial untuk tujuan penelitian dan pengembangan; pengelola destinasi dapat mengembangkan konten virtual tourism dibawah pendampingan dari akademisi; serta wisatawan dapat terlibat dalam uji coba konten dan secara bersama memperbaiki melalui umpan balik dari warga dan wisatawan.

\section{Metode}

Kegiatan pengabdian ini dilakukan bulan Januari-September 2020 dengan menyesuaikan protokol keselamatan Covid 19. Jenis pengabdian ini adalah implementasi action research dengan menggunakan pendampingan. Kelompok sasaran yang dilibatkan dalam kegiatan pendampingan ini adalah pengelola langsung destinasi wisata lab Kampoeng Heritage Kayoetangan yaitu Pokdarwis dengan mengundang perwakilan pemerintah lokal, kelompok komunitas wisatawan, perwakilan warga setempat dengan total 10 orang peserta bertempat di Kampoeng Heritage Kajoetangan dan Laboratorium Pariwisata Universitas Brawijaya, tahapan kegiatan direncanakan sebagai berikut:

Jejak Pendapat dengan Dialog Interaktif

Mengadakan jajak pendapat dan identifikasi permasalahan para aktor yang terlibat dalam model living lab virtual tourism Kampoeng Heritage Kayoetangan seperti pemerintah lokal, pengelola destinasi, akademisi, warga dan wisatawan.

\section{Pendampingan Pembuatan dengan Praktikum Langsung}


Pendampingan akademisi dalam pembuatan konten virtual tourism berdasarkan model living lab Kampoeng Heritage Kayoetangan oleh pengelola destinasi yang terbagi 7 situs di wilayah Kampoeng Heritage Kayoetangan. Tahap ini diharapkan menghasilkan konten virtual tourism berbasis gallery images dari Kampoeng Heritage Kayoetangan yang aman, imersif dan interaktif.

\section{Evaluasi Konten}

Melakukan evaluasi dan umpan balik dari model living lab dan konten virtual tourism yang telah dikembangkan untuk menilai sejauh mana model dapat diaplikasikan, tingkat efektifitas dan efisien model pemberdayaan yang diajukan.

Habituasi dengan Penerapan di Lapangan

Tahap akhir adalah, habituasi melalui implementasi langsung di lapangan model living lab secara sinergitas, simultan dan kontinyu serta pembiasaan penyusunan dan perbaikan konten virtual tourism sehingga dapat terus menyesuaikan perkembangan dan teknologi serta menyelaraskan berbagai kebutuhan aktor yang terlibat khususnya warga dan masyarakat. Tahap ini juga meliputi pemasangan teknologi, penentuan display dan media storage konten virtual tourism di lokasi.

\section{Hasil dan Pembahasan}

Hasil kegiatan pengabdian kepada masyarakat ini dapat diuraikan sebagai berikut:

\section{Jejak Pendapat dengan Dialog Interaktif}

Living lab dalam kegiatan pengabdian kepada masyarakat ini adalah inisiasi dalam bentuk pendampingan kepada pengelola untuk kedepannya mengembangkan inovasi dalam bentuk virtual tourism Kampoeng Wisata Heritage Kojoetangan yang melibatkan pengelola destinasi, wisatawan, warga, pemerintah dan akademisi. Kegiatan dimulai dengan dialog interaktif dimulai dengan mengajukan pertanyaan terbuka tentang apa pandangan pemerintah dan penglola terkait model pendampingan yang selama ini dijalankan dan pengakuan pengelola, wisatawan dan warga apa permasahannya, tantangan atau hambatannya.

Berdasarkan identifikasi tantangan/hambatan yang dibahas dalam sesi awal bisa dikembangkan dalam bentuk pertanyaan-pertanyaan turunan lainnya serta diambil kesimpulan bersama untuk menyusun model alternatif melalui model pendampingan living lab. Tahap ini diharapkan dapat menghasilkan Booklet Pariwisata Virtual untuk Awam sebagai panduan dan dasar pemahaman pengembangan bersama living lab Kampoeng Heritage Kayoetangan serta model living lab virtual tourism Kampoeng Heritage Kayoetangan seperti yang ditampilkan pada Gambar 1.

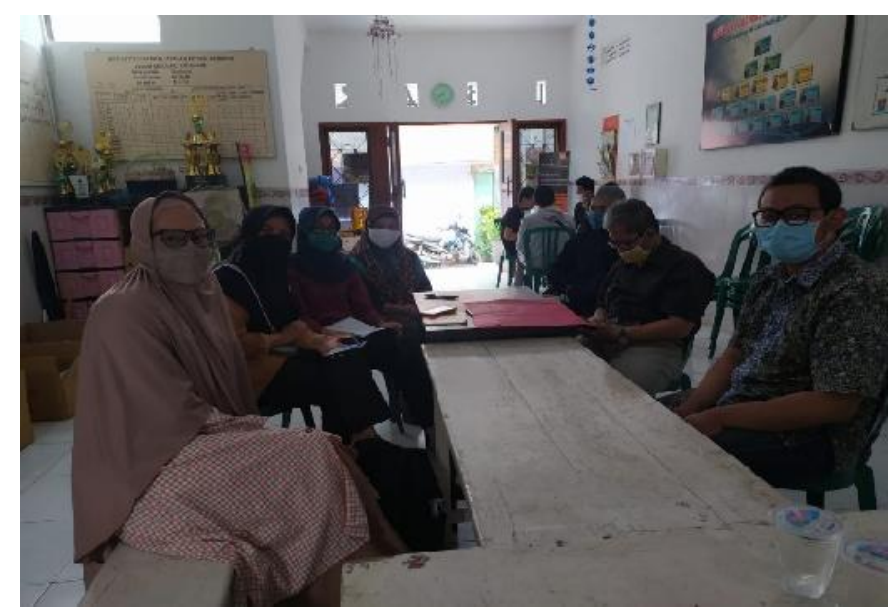

Gambar 1. Jejak Pendapat dengan Pihak Terkait 
Pendampingan Pembuatan dengan Praktikum Langsung

Pembuatan konten terbagi menjadi dua tahap yaitu pertama pengambilan foto $360^{\circ}$ sebagai bahan utama konten virtual tourism berbasis galeri foto $360^{\circ}$ di 7 lokasi situs utama yaitu Rumah Ningrat, Rumah Jacob, Rumah Jamu, Rumah Mbah Ndut, Rumah Jengki, Makam Mbah Ndut dan Pasar Krempyeng dan kemudian dilanjutkan dengan praktikum pembuatan dengan mengolah foto $360^{\circ}$ menjadi konten virtual tourism menggunakan perangkat lunak AFrame seperti yang ditampilkan pada Gambar 2.

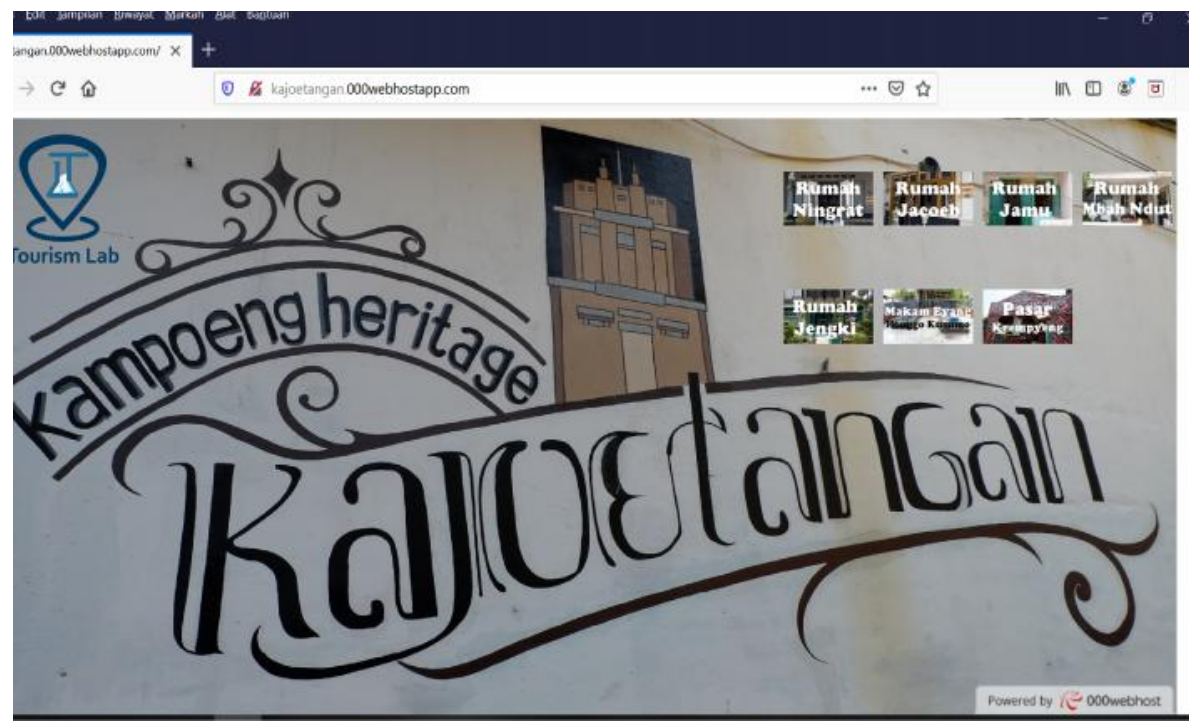

Gambar 2. Tampilan Menu Utama Konten Virtual Tourism

\section{Evaluasi Konten}

Penilaian dilakukan dengan melaksanakan launching perdana konten virtual tourism Kampoeng Heritage Kayoetangan dan uji coba ke wisatawan virtual dengan menggunakan media zoom meeting. Wisatawan virtual dapat mengakases konten virtual tourism kampoeng Heritage Kajoetangan selama sesi diskusi virtual berlangsung dan virtual tour berlangsung dengan dipandu langsung ketua Pokdarwis seperti yang ditampilkan pada Gambar 3.

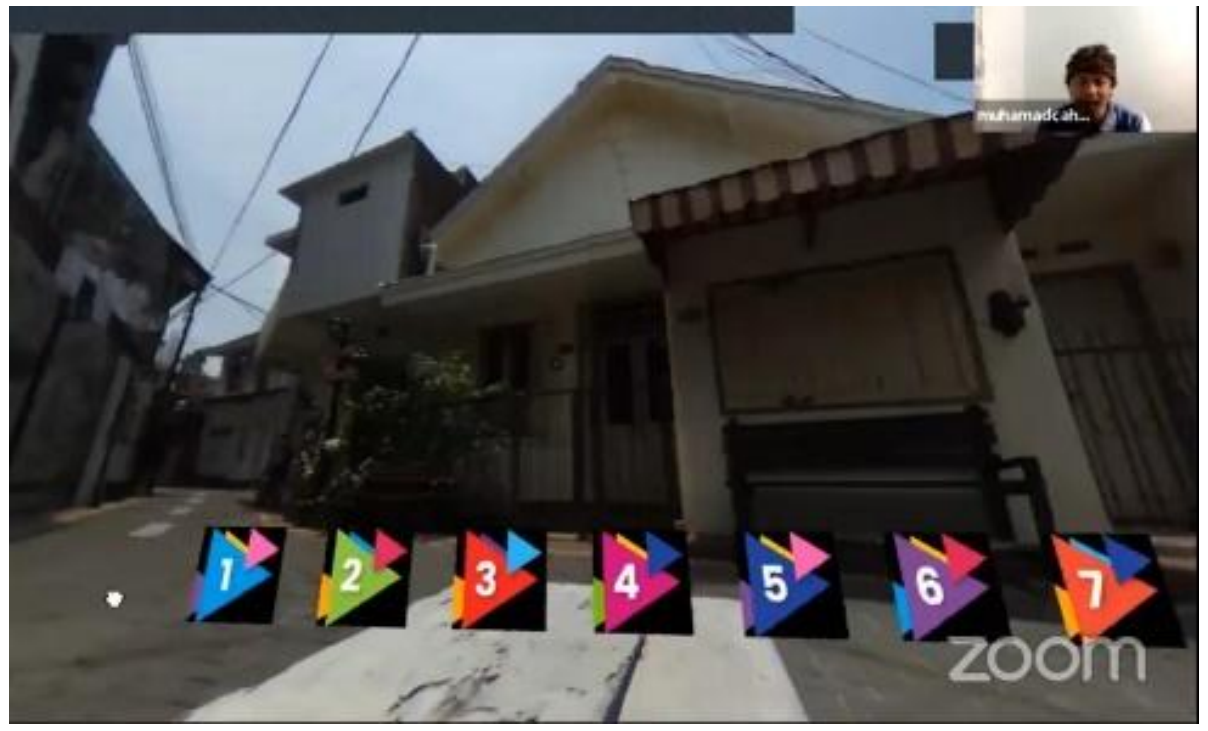

Gambar 3. Uji Coba Perdana Konten Virtual Tourism dengan Zoom Meeting 


\section{Habituasi dengan Penerapan di Lapangan}

Tahap akhir kegiatan pengabdian ini dilakukan dengan meluncurkan "Kampoeng Heritage Kajoetangan Virtual Reality Corner" yang dilengkapi Gear kacamata VR dan booklet Pariwisata Virtual untuk Awam sebagai bentuk preservasi pengetahuan, produk tambahan yang melengkapi destinasi sekaligus media promosi yang interaktif seperti yang ditampilkan pada Gambar 4.

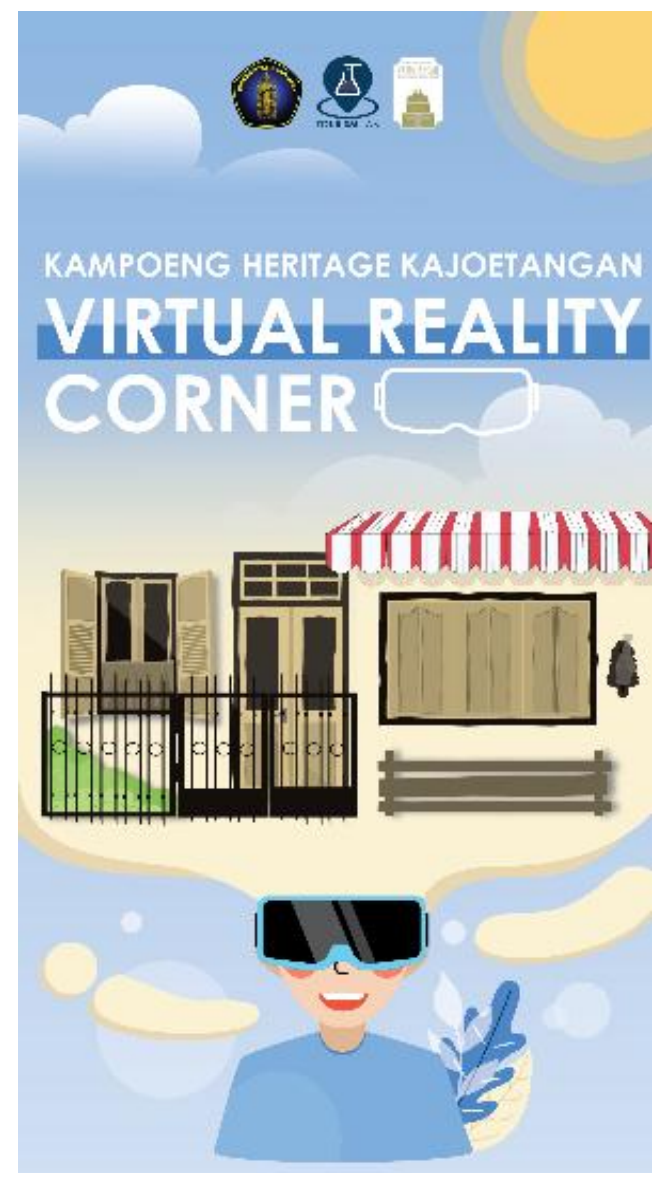

Gambar 4. Virtual Reality Corner Kampoeng Heritage Kajoetangan

Saat ini, berbagai kemajuan dalam teknologi realitas mampu menawarkan aplikasi yang berguna dalam pelestarian situs warisan budaya antara lain melalui pengembangan konten dunia virtual berbasis teknologi virtual reality (VR) (Cirulis et al, 2015) atau yang dikenal dengan istilah virtual tourism. Virtual tourism diyakini dapat menjawab permasalahan pertama dapat pada situs Kampoeng Heritage Kayoetangan melalui pengalihan kuantitas kunjungan wisatawan langsung ke kunjungan virtual pada konten virtual tourism sehingga dapat melengkapi kunjungan nyata melalui pengalaman virtual yang ditawarkan (Hu et al., 2012; Dewailly, 1999) atau digunakan wisatawan sebagai alternatif kunjungan nyata (Kaelber, 2007; Ritzer, 1998; Bristow, 2007, Guttentag, 2010) sehingga privasi, masalah dualisme ruang, keterbatasan akses situs, keamanan rumah cagar budaya dari berbagai ekses negatif wisatawan dapat diminimalisir. Hu et al. (2012) memandang virtual tourism sebagai elemen kegiatan pariwisata yang aman secara ekonomi dan aman dari manusia modern.

Kemudian menjawab permasalahan kedua dan ketiga, virtual tourism menawarkan pengalaman realistis dapat digunakan untuk perencanaan perjalanan wisatawan individu sehingga dapat lebih mempertimbangkan daya dukung dan daya tampung destinasi wisata (Stepaniuk et al, 2014) serta mengurangi ekses negatef pariwisata di lingkungan Kampoeng Heritage Kayoetangan. Tanpa mengambil resiko dan merusak situs warisan, virtual tourism memungkinkan kunjungan ke situs dengan lingkungan sensitif yang tidak cocok untuk banyak pengunjung. Selain itu, dipercayai bahwa dengan diseminasi pengalaman realistis yang ditawarkan oleh aplikasi virtual reality, tekanan 
pengunjung pada area warisan budaya akan berkurang dimana alih-alih menempatkan warisan budaya asli pada risiko kerusakan, tur virtual sebenarnya dapat membantu melindungi situs dengan memungkinkan pengunjung mengakses simulasi dan tetap menikmati situs (Cheong,1995). Virtual tourism dapat memberikan bentuk alternatif akses ke situs dan objek warisan yang terancam yang mengurangi dampak dari kepadatan wisatawan yang berlebihan dan juga pada saat yang sama meningkatkan pengalaman wisatawan secara keseluruhan. Wisata warisan budaya secara digital tidak hanya membantu melestarikan warisan budaya, tetapi juga meningkatkan aksesibilitasnya secara signifikan (Abdul Karim, 2004; Tonta, 2008).

Menjawab permasalah keempat, kemampuan teknologi realitas virtual dalam menyimpan dan menyediakan set data yang sangat tepat dan akurat dapat berguna untuk menyediakan informasi, memantau degradasi dan menyediakan cetak biru untuk restorasi situs dan objek tersebut (Guttentag, 2010). Dengan menggunakan perangkat pemindaian 3D, situs dan benda cagar budaya dapat dikonversi menjadi bentuk digital atau model 3D virtual (Cignoni and Scopigno, 2008) sehingga diyakini virtual tourism Kampoeng Heritage Kayoetangan mampu efektif mengkomunikasikan informasi dari situs cagar budaya sekaligus dapat memberikan kedekatan pengguna dengan teknologi terbaru dan memberikan pengalaman virtual yang imersif dan interaktif, terutama pada wisatawan difabel (Rizzo et al, 2015), manula (Lin et al, 2018) dan millennial (Femenia-Serra et al, 2019).

Virtual tourism pada living lab dapat menjawab permasalahan kelima, yaitu melalui pengembangan bersama pengelola situs cagar budaya untuk membuat tata kelola, perencanaan dan pelaksanaan pengelolaan situs menjadi lebih baik. Kolaborasi antar wilayah dan pihak terkait seperti akademisi, insititusi, perusahaan dan masyarakat (Public. Private, People Partnership) dalam bentuk pengelolaan bersama virtual tourism Kampoeng Heritage Kayoetangan sebagai living lab dapat meningkatkan nilai pengalaman wisata secara konkret dengan mendorong interaksi yang lebih tinggi, co-creation, dan peningkatan personalisasi (Neuhofer, Buhalis, and Ladkin, 2015).

\section{Simpulan}

Kontinum ruang fisik, sosial, dan virtual dalam living lab memungkinkan tata kelola, dialog, dan retensi pengetahuan (di tingkat makro) serta intervensi, keterlibatan pengguna, co-creation, eksperimen, dan evaluasi (di tingkat meso dan mikro). Dalam kasus-kasus dengan dimensi teritorial, seperti industri pariwisata, living lab dapat menyediakan wilayah konsultansi dan kerja sama yang relatif luas seperti ruang pertemuan atau ruang komunitas virtual di mana orang-orang akan berada dalam kedekatan fisik atau kedekatan virtual. Kemudian, ruang fisik atau ruang virtual tersebut akan terikat pada ruang soal kemasyarakatan (Veeckman and Graaf, 2015). Berdasarkan kegiatan pengabdian ini diyakini telah nemberikan ruang bagi akademisi untuk melakukan pengabdian pada real life konteks yang produktif, terfokus, tersinergi, dan berkelanjutan melalui kerjasama dalam satu wilayah living lab khususnya dalam bentuk virtual tourism. Pengelola destinasi telah mampu menghadirkan inovasi produk baru yang mampu meminimalisir ekses negatif pariwisata pada Kampoeng Heritage Kayoetangan dengan menggunakan teknologi virtual tourism. Kedepannya diharapkan keberlanjutan sinergi antar aktor yang terlibat dalam model living lab virtual tourism Kampoeng Heritage Kayoetangan dapat terus ditingkatkan.

\section{Ucapan Terima Kasih}

Kami sampaikan terima kasih kepada pihak yang terlibat dalam kegiatan ini khususnya Laboratorium Pariwisata Fakultas Ilmu Administrasi Universitas Brawijaya, Kelompok Sadar Wisata Kampoeng Heritage Kajoetangan, pemerintah setempat dan masyarakat lokal serta wisatawan virtual pengguna konten virtual tourism Kampoeng Heritage Kayoetangan. 


\section{Referensi}

Ban os, R. M., Botella, C., Alcan iz, M., Lian o, V., Guerrero, B., \& Rey, B. (2004). Immersion and emotion: their impact on the sense of presence. Cyberpsychology \& Behavior, 7(6), 734-741.

Doran, Rouven; Daniel Hanss; Svein Larsen (2015), Attitudes, efficacy beliefs, and willingness to pay for environmental protection when travelling, Tourism and Hospitality Research, Vol. 15(4) 281-29

Ermi, L and F. Mayra (2005), "Fundamental Components of the Gameplay Experience: Analysing Immersion," Proceedings of the DiGRA Conference on Changing Views: Worlds in Play, Vancouver, 16-20 June 2005

Gunttentag, Daniel A. (2010).Virtual reality: Applications and implications for tourism, Tourism Management 31 (2010) 637-651.

Gutie' rrez, M., Vexo, F., \& Thalmann, D. (2008). Stepping into virtual reality. London: Springer.

Handoko, Irfan Tri, Alfian Muflih Huda, Sahna Melly Marselina, Rahmadi Wijaya, S.Si., M.T., Fat'hah Noor Prawita, S.T., M.T. (2015) Bandung Advanced Tour Game Petualangan Wisata Bandung Berbasis Mobile Menggunakan Teknologi Virtual Reality, e-Proceeding of Applied Science : Vol.1, No.2 Agustus 2015 | Page 1187-1197

Hyun, M.Y., \& O'Keefe, R.M. (2012). Virtual destination image: Testing a telepresence model. Journal of Business Research, 65, 29-35

Klein, L.R. (2003). Creating virtual product experiences: The role of telepresence. Journal of Interactive Marketing, 17(1), 41-55.

Sanchez-Vives, M. V., \& Slater, M. (2005). From presence to consciousness through virtual reality. Nature Reviews Neuroscience, 6(4), 332-339

Slater, M (2003) "A Note on Presence Terminology," Presence-Connect, Jan. 2003; http://presence.cs.ucl.ac.uk/presenceconnect/articles/Jan2003/melslaterJan27200391557/melsl aterJan27200391557.html.

Spielmann, Nathalie, Antonia Mantonakis, Barry J. Babin, and Aikaterina Manthiou (2016) ,"The Telepresence Effect: Changing Attitudes Via Virtual Tours in Marketing Communications", in NA - Advances in Consumer Research Volume 44, eds. Page Moreau and Stefano Puntoni, Duluth, MN : Association for Consumer Research, Pages: 759-759.

Suh, K.-S., \& Lee, Y.E. (2005). The effects of virtual reality on consumer learning: An empirical investigation. MIS Quarterly, 29(4), 673-697.

Tussyadiah, I.P., Wang, D., \& Jia, C.H. (2017). Virtual reality and attitudes toward tourism destinations. In Schegg, R., \& Stangl, B. (Eds.), Information and Communication Technologies in Tourism 2017. Springer International Publishing

Vince, J. (2004). Introduction to virtual reality. New York: Springer.

Witmer, Bob G and Michael J Singer (1998). Measuring presence in virtual environments: A presence questionnaire. Presence: Teleoperators and virtual environments, 7(3):225-240. 